\title{
Assessment on management of late blight in tomato incited by Phytophthora infestans
}

\author{
B. MANJUNATH ${ }^{1 *}$, C.P. MANJULA ${ }^{2}$, JAHIR BASHA ${ }^{3}$, K.N.SRINIVASAPPA ${ }^{1}$ AND MANJUNATH \\ GOWDA $^{4}$ \\ ${ }^{1}$ Krishi Vigyan Kendra (BRD), HADONAHALLI (KARNATAKA) INDIA \\ ${ }^{2}$ Department of Plant Pathology, University of Agricultural Sciences, G.K.V.K., BENGALURU (KARNATAKA) INDIA \\ ${ }^{3}$ Agricultural Research Station, PAVAGADA(KARNATAKA) INDIA \\ ${ }^{4}$ Krishi Vigyan Kendra, CHIKKABALLAPUR (KARNATAKA) INDIA
}

\section{ARITCLE INFO}

Received : 23.03 .2017

Revised : 23.08 .2017

Accepted : 05.09 .2017

\section{KEY WORDS :}

Biocontrol agents, Disease severity,

Fungicides, Late blight, Management

*Corresponding author:

Email: manjunathkrishi@gmail.com

\begin{abstract}
:
Late blight incited by Phytophthora infestansis one of the most widelyspread and economically important disease of tomato. The present investigation was carried out to evaluate the efficacy of different fungicides and biocontrol agents for the management of the disease. Soil application of Trichoderma viride and Pseudomonas fluorescens 15 days before transplanting followed by prophylactic spray of Mancozeb (0.2\%) 25 days after transplanting was found effective. Three sprays of fungicides viz., Metalaxyl+Mancozeb (0.2\%), Fosetyl-Al (0.2\%) and Dimethomorph (0.1\%)+Polyram $(0.2 \%)$ sprayed at regular intervals of ten, twenty and thirty days depending on the disease severity was found very effective in managing the disease.
\end{abstract}

How to view point the article : Manjunath, B., Manjula, C.P., Basha, Jahir, Srinivasappa, K.N. and Gowda, Manjunath (2017). Assessment on management of late blight in tomato incited by Phytophthora infestans. Internat. J. Plant Protec., 10(2) : 349-353, DOI : 10.15740/HAS/IJPP/ 10.2/349-353.

HIND AGRICULTURAL RESEARCH AND TRAINING INSTITUTE 